\title{
From Viral City to Smart City: Learning from Pandemic Experiences
}

\section{Da Cidade Viral à Cidade Inteligente: Lições da Experiência Pandémica}

Constantino SAKELLARIDES $\triangle 1$

Acta Med Port 2020 Jun;33(6):359-361 - https://doi.org/10.20344/amp.13841

Keywords: Coronavirus; COVID-19; Emergencies; Pandemics; Public Health

Palavras-chave: Coronavírus; COVID-19; Emergências; Pandemia; Saúde Pública

\section{Flu city, Smart city}

Public health global threats have become increasingly frequent over the last two decades: Avian flu, SARS, H1N1 flu, MERS, Ebola, Zika and now COVID-19.

Looking at the way public health preparedness took place regarding avian flu and SARS global threats, it seemed apparent that there was a striking discontinuity between ongoing community health practices and the command-and-control mode of public health emergency preparedness and action.

This issue was addressed in a short assay - Flu CitySmart City: applying health promotion principles to a pandemic threat ${ }^{1}$ - in 2006. A mindset change, from threat to ingenuity, is suggested: "The critical triangle consists of a unique and dynamic inter-face between three components: knowledge, values and innovation. If we want to be prepared for a major flu epidemic, we must understand not only the virus and how it spreads but also cities and how they function, organizations and how they operate, communities and how they relate, and individuals and how they make choices".

In preparing for and following the development of the $2009 \mathrm{H} 1 \mathrm{~N} 1$ flu pandemic, this same framework was adopted to analyze the 'social response' to the pandemic threat. ${ }^{2}$ However, the aftermath of the 2009 pandemic turned out to be unfriendly to innovative thinking. The $\mathrm{H} 1 \mathrm{~N} 1$ virus was partially 'known' by the aged; disease incidence was comparable to that of a moderate seasonal flu, which led to community perceptions that the approaches adopted for preparing for the pandemic where exaggerated; the acquisition of large amounts of antiviral oseltamivir were sharply criticized; there was limited adherence to the vaccination program for the mildly pandemic H1N1. Nevertheless, the traditional public health emergency model came out untouched from this pandemic experience.

In "The next outbreak? We are not prepared", Bill Gates stressed in $2015,{ }^{3}$ that we were well prepared for the next war, but not equally well prepared for the next pandemic. Gates addressed the hardware and software of global preparedness but not the "humanware" of local community intelligence.
Neither were part of this pandemic preparedness. ${ }^{4}$

\section{Current pandemic experiences}

Yuval Harari, ${ }^{5}$ addressed the issue of 'the world after the coronavirus' in a recent article in the Financial Times. He pays particular attention to developments related to this pandemic in Hong-Kong, South Korea, Singapore and Taiwan. Harari stresses the fact that, while these countries made use of tracking applications to monitor population dynamics related with behaviors around disease transmission, they have relied far more on "extensive testing, on honest reporting and on willing co-operation of a well-informed community".

At the same time, a Hong Kong journalist, Gary Liu, ${ }^{6}$ provided us with a more detailed account of what has been happening in that territory. The memory of the SARS epidemic did sink deeply into the collective behavior in the territory: a deep concern about environmental hygiene, a new consciousness about the role of social distancing under different circumstances, an enhanced ability and willingness to communicate about issues of common interest and a sense of the importance of trust and cooperation, regardless of government initiatives.

Finally, from the very epicenter of the Italian epidemic, during the most acute phase of this crisis, Mirco Narcoti and a group of healthcare professionals working at the Papa Giovanni XXIII Hospital in Bergamo, claim, in a paper published in the New England Journal of Medicine (NEJM), ${ }^{7}$ that in a pandemic, patient-centered care adopted by western healthcare systems is inadequate and must be replaced by community- centered care. Solutions for COVID-19 are required for the entire population, not only for hospitals. They call for a long-term plan for the next pandemic.

In Portugal, as in almost elsewhere, we observe an extraordinary increase in knowledge sharing in neighborhoods, between families and friends, academics and professionals, cultural associations and the public, the media and in almost all societal strata. New information gathering and distribution tools are being developed ${ }^{8}$ in order to stimulate community collaborative intelligence.

\footnotetext{
1. Professor Catedrático jubilado. Escola Nacional de Saúde Pública. Universidade NOVA de Lisboa. Lisboa. Portugal.

$\square$ Autor correspondente: Constantino Sakellarides. sak@ensp.unl.pt

Recebido: 02 de abril de 2020 - Aceite: 13 de abril de 2020 | Copyright @ Ordem dos Médicos 2020
} 
Learning from pandemics - public health emergencies and smart communities

One reason that explains the limited learning from one public health crisis to the next is the exclusive adherence to the traditional model of public health emergencies rather than community health protection and promotions practices. It is obvious that the more authoritarian dimension of public health emergencies will have a strong role, at certain times. However, it is more likely that it will be effective if preceded, joined and followed by a higher level of community health intelligence (Fig. 1).

In fact, this is about two complementary mindsets:

- A public health emergency centralized and normative management, centered on biomedical sciences and epidemiology, where success depends on the adherence to centrally established norms.

- A "smart community", which is creative and supported by a multidisciplinary knowledge base and centered on highly developed collaborative intelligence. This is defined as the ability and willingness to share critical health knowledge aimed at converging towards action conducive to the attainment of common goals, and jointly learning from experience. ${ }^{9}$ Smart communities adapt rapidly to new circumstances, rely on well established, trusted community networks, and take advantage of current data availability and computational power. ${ }^{10-12}$

Morens, Daszak and Taubenberger ${ }^{13}$ argue convincingly that we have reached the current situation because of "continuing increases in the human population, crowding, human movement, environmental changes, and eco- systemic complexity related to human activities and creations".

One can anticipate that the smart communities we need in the coming years are those that can adopt different proximity and distancing architectures - daily, weekly, monthly and yearly - according to a number of adaptative criteria, allowing for a more appropriate response to a large variety of living requirements: how we learn during school age, according to student profiles and local circumstances; different ways to organize work and how each one is engaged in contributing to organizational diversity and flexibility; better timing and balancing between work and leisure time and in gender roles, in home living; more effective, innovative and environmentally friendly mobility management, benefiting from novel tracking technologies; greater opportunities and personalized support, when needed, for physical and mental health fitness; easier access, through personal contacts or more 'distant' interactions, with health and social services; enhanced environmental consciousness and rationality in daily living; progress towards more participatory democracy and well-being policies and economies.

These developments will also provide an effective common platform for swift, multipolar and effective action against acute and sustained public health threats. This is made possible by early alert systems based on better monitoring of the interface between human and other animal species, enhancing collaborative intelligence and slowing down avoidable risk-taking whenever necessary.

A second-generation National Health Service, responding more effectively to the challenges of our time is certainly a key ingredient of smarter communities.

\section{Pandemic-related intermediate development stages}

During the current COVID-19 epidemic outbreak strict stay-at-home policies have been adopted by many countries. As the epidemic curve subsides and community life is progressively restored, critical challenges can be

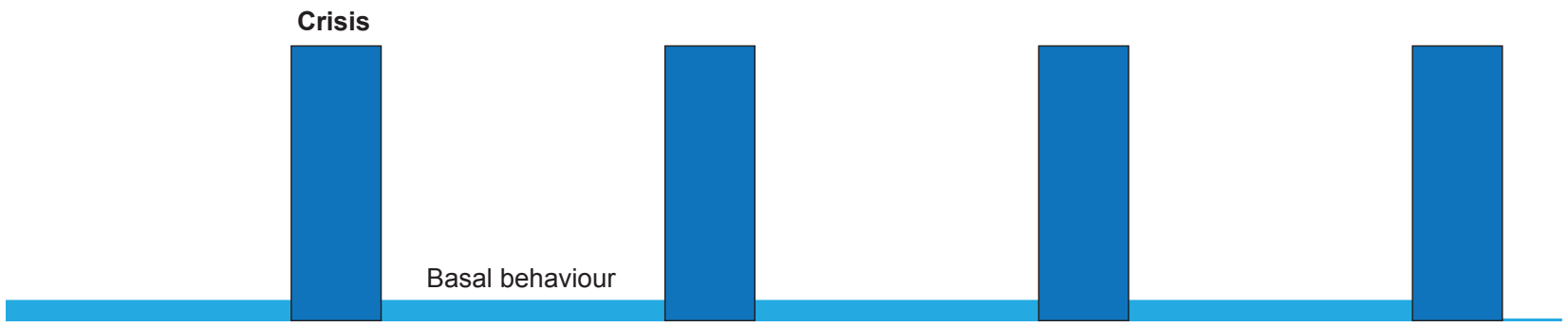

Public health emergency and basal behaviour - unchanged pathway

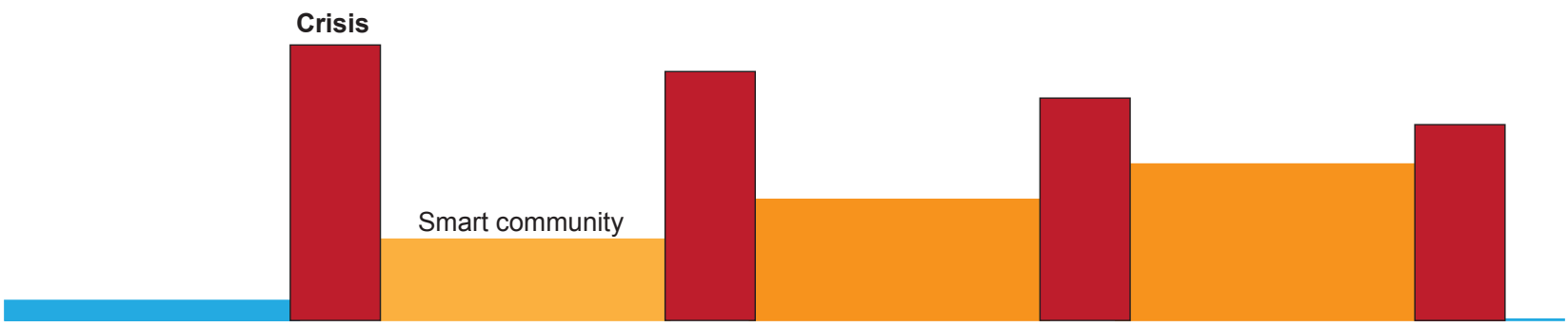

Public health emergency and smart communities - learning pathway

Figure 1 - From a non-learning unchanged pathway from one public health emergency to the next one to a learning one centered on evolving smart communities influencing public health emergencies 
considered opportunities for change. Even if somewhat limited in scope under current circumstances, we already need to move in the right direction. The expected erosion of social and political convergence after the more dramatic phase of the pandemic requires clear minded and well-informed public policies.

Public alertness to health risks, enhanced interconnectivity and improved competence in looking for and interpreting health related information, can enhance the upgrade of current health literacy strategies ${ }^{14}$ towards a more intelligent community. In this context, phasing out the current lockdown status will require different local strategies that effectively combine local epidemiological features with the ability of local communities to respond appropriately to these epidemiological patterns.

The focus on people with multimorbidity and on the elderly during the current outbreak calls for decisive steps towards person-centered integrated care. New arrangements aimed at bring primary, hospital, long term and social care

\section{REFERENCES}

1. Kickbusch I, Sakellarides C. Flu City-Smart City: applying health promotion principles to a pandemic threat. Health Promot Int. 2006;21:85-7.

2. Sakellarides C. Nós e a gripe. Lisbon: Gradiva, 2010.

3. Gates B. The next outbreak? We are not ready. Vancouver: TED; 2015

4. Gates B. How we must respond to the coronavirus epidemic. Monterey: TED; 2020

5. Harari Y. The world after the coronavirus. London: Financial Times; 2020

6. Liu G. What the world can learn from China's response to the coronavirus. Monterey: TED; 2020.

7. Nacoti M, Ciocca A, Giupponi A, Brambillasca P, Lussana F, Pisano M, et al. At the epicentre of the Covid-19 epidemic and humanitarian crises in Italy: Changing perspectives on preparation and mitigation. NEJM Catalyst. 2020. (in press).

8. Escola Nacional de Saúde Pública. Barómetro - opinião social COVID-19. [accessed 2020 Mar 28]. https://www.ensp.unl.pt/investigacao/ barometro-covid-19/opiniao-social/

9. Sakellarides C, Escoval A, Barbosa P, Santos AI, Pedro AR, Miranda, $D$. Health systems at the stage of complexity: The need for collaborative intelligence In: Health Care and Government Policy [online]. Évora: Publicações do Cidehus; 2019.

10. Inclezan D, Prádanos L. View point: a critical view on smart cities and AI. J Artig Intell Res. 2017;60:681-6.

11. Boulos M, Peng G, VoPham T. Review of GeoAl applications in health and health care. Int J Health Geogr. 2019;18:7.

12. Wilson $\mathrm{HJ}$, Daugherty PR. Collaborative intelligence: humans and $\mathrm{Al}$ are closer together are now of paramount importance. ${ }^{15}$ These are likely to provide further stimuli for change in all these sectors: home care and increased telephone and video consultations and referrals ${ }^{16-18}$; better defined roles in the health system for hospitals ${ }^{19}$; immediate and forceful adoption of personal care plans for managing long term care and anticipating acute needs ${ }^{20}$; better recognition of the relevance of social prescribing. ${ }^{21}$

The extraordinary performance of healthcare professionals and the personal risks they incurred during the current crisis will also provide further impetus for a new kind of policies favoring better working conditions for the healthcare professions.

Finally, the reset of national, European, and global economies could also provide an opportunity for more wellbeing economies and budgets. ${ }^{22}$

We are all experiencing dramatic times. Forward looking is not an act of redemption but a personal and professional obligation.

joining forces. Harv Bus Rev. 2018:3-11.

13. Morens D, Daszak P, Taubenberger J. Escaping Pandora's box - another novel coronavirus. N Engl J Med. 2020;382:1293-5.

14. Silva Costa A, Arriaga M, Veloso Mendes R, Miranda D, Barbosa P, Sakellarides $C$, et al. A strategy for the promotion of health literacy in Portugal, centered around the life-course approach: the importance of digital tools. Port J Public Health. 2019:1-5.

15. Timmins N. Leading for integrated care. If you think competition is hard, you should try collaboration. London: The King's Fund; 2019.

16. Oliver D. Covid-19 will make us stop some activities for good. BMJ. 2020;369:m1148.

17. Thornton J. Covid-19: how coronavirus will change the face of general practice forever. BMJ. 2020;369:m1148 doi: 10.1136/bmj.m1279.

18. Keesara S, Jonas A, Schulman K. Covid-19 and health care's digital revolution. N Engl J Med. 2020 (in press). doi: 10.1056/NEJMp2005835.

19. Durán A, Wright $S$, editors. Understanding hospitals in changing health systems. London: Palgrave Macmillan; 2020.

20. Portugal, Ministério da Saúde. SNS+ Proximidade. Mudança centrada nas pessoas. Lisboa: Ministério da Saúde; 2017.

21. Figueiredo C, Coelho A. Projeto Piloto de Prescrição Social de Lisboa, USF da Baixa. 13 ${ }^{a}$ edição do Prémio de Boas Práticas em Saúde. Lisboa: Associação Portuguesa para o Desenvolvimento Hospitalar; 2019

22. New Zealand Government. The Wellbeing Budget. Wellington: New Zealand Government; 2019. 